\author{
O.S. Kaimieva ${ }^{a}$, I. E. Sabirova ${ }^{a}$, \\ E. S. Buyanova ${ }^{a}$, S. A. Petrova ${ }^{\text {b }}$ \\ ${ }^{a}$ Institute of Natural Sciences and Mathematics, Ural Federal University, \\ 19 Mira st., Ekaterinburg 620002, Russia \\ ${ }^{b}$ Institute of Metallurgy, Ural Branch of Academy of Sciences, \\ 101 Amundsena st., Ekaterinburg 620026, Russia \\ e-mail:kaimi-olga@mail.ru
}

\title{
Synthesis and Properties of Vanadium Substituted Bismuth Tungstates with Fluorite-like Structure
}

The samples of vanadium substituted bismuth tungstates with a cubic structure were obtained by solid state method. The unit cell volume of the compounds slightly contracts with increasing tungsten content and in case of vanadium doping. Thermal expansion coefficient of bismuth tungstate is equal to $13 \cdot 10^{-6}{ }^{\circ} \mathrm{C}^{-1}$. The electrical conductivity was investigated using ac impedance spectroscopy. The results showed that the substitution of tungsten with vanadium ions increased electrical conductivity values by one order of magnitude.

Keywords: bismuth tungstate; fluorite-like structure; oxide-ion conductivity; solid electrolyte.

Received: 05.07.2019. Accepted: 23.07.2019. Published: 05.08.2019.

(C) Kaimieva O. S., Sabirova I. E., Buyanova E. S., Petrova S. A., 2019

\section{Introduction}

$\delta-\mathrm{Bi}_{2} \mathrm{O}_{3}$ has the highest value of electrical conductivity $\left(1-1.5 \mathrm{Ohm}^{-1} \mathrm{~cm}^{-1}\right)$ among all known complex oxide electrolyte materials for electrochemical devices $[1,2]$. The main disadvantage of this phase is that it is stable only within a limited temperature range $\left(730-825^{\circ} \mathrm{C}\right)$. A large number of studies are connected with searching for the best way of its stabilization at room temperature preserving its characteristics. For this purpose, substitution with various suitable ions $\left(\mathrm{Nb}^{5+}, \mathrm{Mo}^{6+}, \mathrm{Ta}^{5+}, \mathrm{Ti}^{4+}\right.$, $\mathrm{W}^{6+}$ etc.) is usually used [1-4]. It is found for $\mathrm{Bi}_{2} \mathrm{O}_{3}-\mathrm{WO}_{3}$ system that the introduction of tungsten oxide (more than $9 \mathrm{wt} . \%$ ) is a necessary condition for stabilization of $\delta$-phase $\mathrm{Bi}_{2} \mathrm{O}_{3}$ [5]. Otherwise, $\beta-\mathrm{Bi}_{2} \mathrm{O}_{3}$ appears. On the other hand, a homogeneity area of cubic structure on the phase diagram exists between compounds with compositions 2:1 and 5:1. $\mathrm{Bi}_{6} \mathrm{WO}_{12}$ has fluorite-like structure as well. This compound melts congruently at $1040{ }^{\circ} \mathrm{C}$ and has reversible phase transition at $900{ }^{\circ} \mathrm{C}$. So, as it was shown by Wind [6, 7], bismuth tungstates with a fluorite-like structure are promising as compounds which have values of electrical conductivity comparable with those of yttria-stabilized zirconia. Three more stable cubic phases, $\mathrm{Bi}_{22} \mathrm{~W}_{5} \mathrm{O}_{48}, \mathrm{Bi}_{22} \mathrm{~W}_{4.5} \mathrm{O}_{47.25}$, and $\mathrm{Bi}_{23} \mathrm{~W}_{4} \mathrm{O}_{46.5}$, were obtained at room temperature via quenching $[6,7]$. In case of low cooling rate, a phase transition from cubic to tetragonal structure occurs at $700{ }^{\circ} \mathrm{C}$. Until now, many authors have agreed that the phase diagram of $\mathrm{Bi}_{2} \mathrm{O}_{3}-\mathrm{WO}_{3}$ system is complex enough and requires a de- 
tailed study. Takahashi and Iwahara [8] have done research on ionic properties of $\left(\mathrm{Bi}_{2} \mathrm{O}_{3}\right)_{1-x}\left(\mathrm{WO}_{3}\right)_{x}(x=0.05-0.5)$ and found extremely high oxide-ion conductivity for the $f c c$ structure over the wide range of temperatures, up to at least $850^{\circ} \mathrm{C}$. The conductivities in $\left(\mathrm{Bi}_{2} \mathrm{O}_{3}\right)_{0.78}\left(\mathrm{WO}_{3}\right)_{0.22}$ are 0.01 and $0.15 \mathrm{Ohm}^{-1} \mathrm{~cm}^{-1}$ at 500 and $880^{\circ} \mathrm{C}$, respectively. The oxide ion transfer number is close to 1 down to oxygen partial pressure $p\left(\mathrm{O}_{2}\right)=10^{-15} \mathrm{~atm}$ [8].

There data on substituted bismuth tungstates $\mathrm{Bi}_{22} \mathrm{~W}_{5} \mathrm{O}_{48}, \mathrm{Bi}_{22} \mathrm{~W}_{4.5} \mathrm{O}_{47.25}, \mathrm{Bi}_{23} \mathrm{~W}_{4} \mathrm{O}_{46.5}$ have not been found in literature. Therefore, the aim of this work is to obtain and study of the structure and physicochemical properties of bismuth tungstates doped with vanadium ions.

\section{Experimental}

$\mathrm{S}$ amples $\quad \mathrm{Bi}_{22} \mathrm{~W}_{5-x} \mathrm{~V}_{x} \mathrm{O}_{48-\delta}$, $\mathrm{Bi}_{22} \mathrm{~W}_{4.5-x} \mathrm{~V}_{x} \mathrm{O}_{47.25-\delta}, \mathrm{Bi}_{23} \mathrm{~W}_{4-x} \mathrm{~V}_{x} \mathrm{O}_{46.5-\delta}(x=0.0$; 0.1 ) were prepared by solid-state method. Metal oxides $\mathrm{Bi}_{2} \mathrm{O}_{3}(99.99 \%), \mathrm{WO}_{3}(99.9 \%)$, $\mathrm{V}_{2} \mathrm{O}_{5}(99.9 \%)$ were taken as precursors. The multi-step synthesis was carried out in the temperature range $400-1000{ }^{\circ} \mathrm{C}$. Annealing time was 8 hour at each stage. The synthesis into pressed bars was performed after annealing of powder samples at $700{ }^{\circ} \mathrm{C}$. The samples were quenched after the last stage of the synthesis. The phase composition of the powders was determined by means of X-ray powder diffraction (DRON3 diffractometer, Russia, $\mathrm{Cu} \mathrm{Ka}$ radiation). The phase purities of the compounds were confirmed by comparing their XRD patterns with those in the PDF2 database. The density of sintered bars was estimated by Archimedes method.

\section{Results and discussion}

According to results of X-ray diffraction analysis, all obtained compounds were single-phase with cubic structure (space group $\mathrm{Fm} 3 \mathrm{~m}$ ). X-ray diffraction patterns of the $\mathrm{Bi}_{22} \mathrm{~W}_{5-x} \mathrm{~V}_{x} \mathrm{O}_{48-\delta}, \mathrm{Bi}_{22} \mathrm{~W}_{4.5-x} \mathrm{~V}_{x} \mathrm{O}_{47.25-\delta}$, $\mathrm{Bi}_{23} \mathrm{~W}_{4-x} \mathrm{~V}_{x} \mathrm{O}_{46.5-\delta}(x=0.0-0.1)$ are given in Fig. 1. The unit cell parameters are listed in Table 1. As the radius of vanadium ions is smaller than that of tungsten ions $\left(r\left(\mathrm{Bi}^{3+}\right)\right.$ $=0.60 \AA ; r\left(\mathrm{~W}^{6+}\right)=0.60 \AA ; r\left(\mathrm{~V}^{5+}\right)=0.54 \AA$ [9]), one can observe slight contraction
Dilatometric measurements were carried out on rectangular bars with the length of $23 \mathrm{~mm}$ using a DIL $402 \mathrm{C}$ Netzsch dilatometer in the temperature range $20-900^{\circ} \mathrm{C}$ with a heating rate of $2{ }^{\circ} \mathrm{C} / \mathrm{min}$. The electrical conductivity values were found by ac impedance spectroscopy method (impedance meter Z-3000 "Elins", Russia) using two-probe cell. The measurements were performed in the temperature range 850$200^{\circ} \mathrm{C}$ and frequency span $3 \mathrm{MHz}-1 \mathrm{~Hz}$ at the cooling mode. Obtained impedance spectra were treated with "ZView" software and equivalent circuits were fitted to them. Using these data, the temperature dependences of electrical conductivity $(\sigma)$ were plotted in Arrhenius coordinates - $\lg \sigma-$ 1000/T.

of unit cell volume of the substituted compounds. The same tendency is found for the samples with increasing tungsten content and is reported in [6,7]. On the whole, all experimental data which are obtained in the present work for matrix compounds are in a good agreement with previous results $[6,7]$.

For the further dilatometric and electrical conductivity measurements, the bismuth tungstates were pressed and sintered 
into bars. Volume porosity of the ceramics obtained at $850^{\circ} \mathrm{C}$ was estimated by Archimedes method. The average value was $10 \%$. For the $\mathrm{Bi}_{23} \mathrm{~W}_{4} \mathrm{O}_{46.5}$ sample, a peak was observed on the cooling curve of thermal expansion coefficient (TEC) near

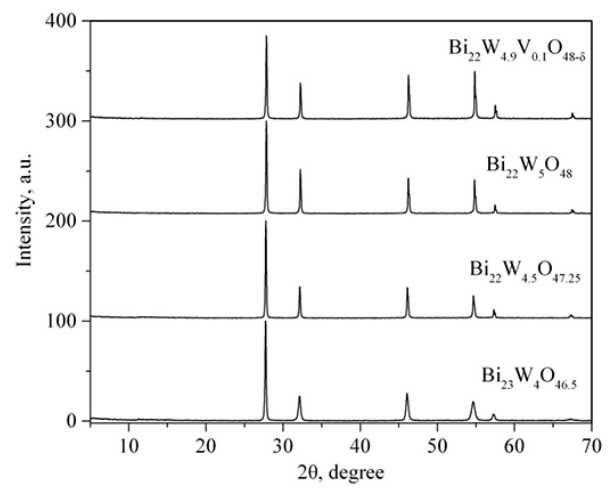

Fig. 1. X-ray diffraction pattern of the bismuth tungstates

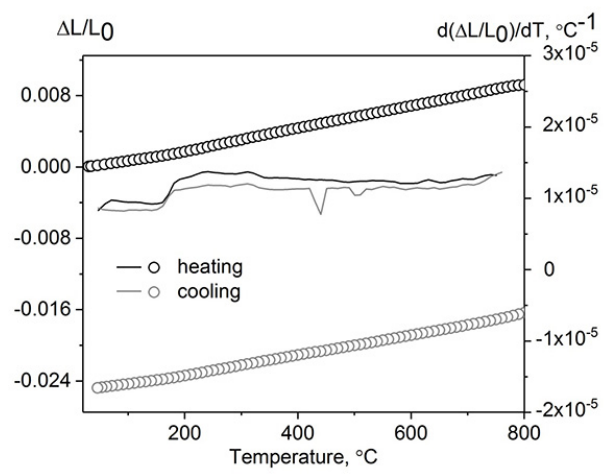

Fig. 2. Temperature dependence of linear thermal expansion and TEC for the sample

$$
\mathrm{Bi}_{23} \mathrm{~W}_{4} \mathrm{O}_{46.5}
$$

$430{ }^{\circ} \mathrm{C}$ (Fig. 2). This peak can be related to the presence of the phase transition from cubic to tetragonal structure $[6,7]$. TEC value of the $\mathrm{Bi}_{23} \mathrm{~W}_{4} \mathrm{O}_{46.5}$ equals to $13 \cdot 10^{-6}{ }^{\circ} \mathrm{C}^{-1}$ and is close to that for lanthanum manganite cathode materials. As the temperature of the measurement $\left(900{ }^{\circ} \mathrm{C}\right)$ was higher than that for sintering of the bar $\left(850^{\circ} \mathrm{C}\right)$, there is hysteresis between the heating and cooling curves on the temperature dependence of linear thermal expansion (Fig. 2).

The electrical conductivity was investigated by ac impedance spectroscopy using two-probe method. Introducing of vanadium ions into the structure of bismuth tungstate leads to significant reduction of samples' resistance. The equivalent circuits were matched to impedance spectra to describe processes taking place in the samples during the measurements (Fig. 3). The circuits can be divided into two types. For the hightemperature range, general resistivity of the samples can be defined (R1) (Fig. 3). Other elements of this circuit (R2+CPE1, $\mathrm{R} 3+\mathrm{CPE} 2$ ) are related to electrode processes because the value of their capacity is equal to $4 \times 10^{-4} \mathrm{~F}$. But at low temperatures it is possible to estimate volume and grain boundary contribution to the electrical conductivity value (Fig. 3). For example, for the composition $\mathrm{Bi}_{22} \mathrm{~W}_{4.9} \mathrm{~V}_{0.1} \mathrm{O}_{48-\delta}$, the volume resistance (R1) equals to $14 \mathrm{kOhm}$ at capacity (CPE1)

Table 1

The unit cell parameters of the bismuth tungstates

\begin{tabular}{c|c|c}
\hline Composition & $A \pm 0.001, \AA$ & $V \pm 0.03, \AA^{3}$ \\
\hline $\mathrm{Bi}_{23} \mathrm{~W}_{4} \mathrm{O}_{46.5}$ & 5.569 & 172.73 \\
\hline $\mathrm{Bi}_{23} \mathrm{~W}_{3.9} \mathrm{~V}_{0.1} \mathrm{O}_{46.5-\delta}$ & 5.569 & 172.60 \\
\hline $\mathrm{Bi}_{22} \mathrm{~W}_{4.5} \mathrm{O}_{47.25}$ & 5.562 & 172.05 \\
\hline $\mathrm{Bi}_{22} \mathrm{~W}_{4.4} \mathrm{~V}_{0.1} \mathrm{O}_{47.25-\delta}$ & 5.558 & 171.72 \\
\hline $\mathrm{Bi}_{22} \mathrm{~W}_{5} \mathrm{O}_{48}$ & 5.549 & 170.85 \\
\hline $\mathrm{Bi}_{22} \mathrm{~W}_{4.9} \mathrm{~V}_{0.1} \mathrm{O}_{48-\delta}$ & 5.546 & 170.60
\end{tabular}



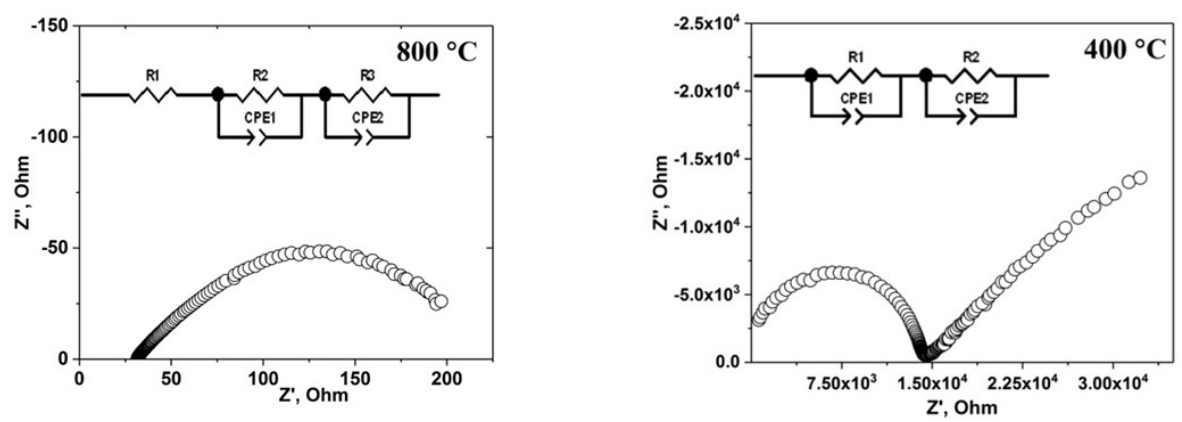

Fig. 3. Impedance spectra of the $\mathrm{Bi}_{22} \mathrm{~W}_{4.9} \mathrm{~V}_{0.1} \mathrm{O}_{48-\delta}$ at $800{ }^{\circ} \mathrm{C}$ and $400{ }^{\circ} \mathrm{C}$

$3 \times 10^{-11} \mathrm{~F}$, the grain boundary resistance (R2) to $185 \mathrm{kOhm}$ at $2 \times 10^{-5} \mathrm{~F}$ (CPE2). Temperature dependences of the general electrical conductivity of the bismuth tungstates were plotted using the data of the impedance spectra (Fig. 4). The results show that the substitution of tungsten with vanadium ions increases electrical conductivity values by one order of magnitude. The activation energy values for all bismuth tungstates are between 0.88-1.02 eV (Table 2), indicating that the samples have ionic type of conductivity. According to our measurements, $\mathrm{Bi}_{23} \mathrm{~W}_{3.9} \mathrm{~V}_{0.1} \mathrm{O}_{46.5-\delta}$ possesses the highest conductivity of all oxides studied $\left(\sigma_{850}=\right.$ $\left.0.13 \mathrm{Ohm}^{-1} \mathrm{~cm}^{-1}\right)$.

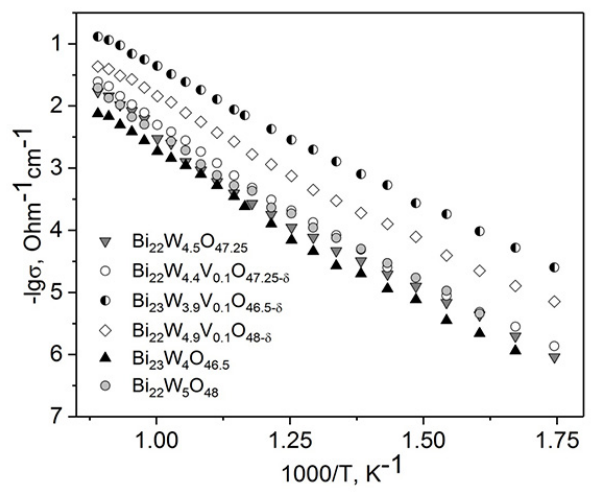

Fig. 4. Temperature dependences of the general electrical conductivity of the bismuth tungstates

\section{Conclusions}

To sum up, the solid solutions based on bismuth tungstates with fluorite-like structure were obtained by solid state method.

The unit cell volume of the compounds slightly contracts with increasing tungsten content and in case of vanadium doping.

Table 2

Electrical conductivity $(\sigma)$ and activation energy $\left(\mathrm{E}_{\mathrm{a}}\right)$ values of the bismuth tungstates

\begin{tabular}{c|c|c|c}
\hline Composition & $\mathrm{E}_{\mathrm{a}}, \mathrm{eV}$ & $\sigma_{750,} \mathrm{Ohm}^{-1} \mathrm{~cm}^{-1}$ & $\sigma_{500,} \mathrm{Ohm}^{-1} \mathrm{~cm}^{-1}$ \\
\hline $\mathrm{Bi}_{23} \mathrm{~W}_{4} \mathrm{O}_{46.5}$ & 0.99 & $7.74 \cdot 10^{-2}$ & $1.30 \cdot 10^{-2}$ \\
\hline $\mathrm{Bi}_{23} \mathrm{~W}_{3.9} \mathrm{~V}_{0.1} \mathrm{O}_{46.5-\delta}$ & 0.88 & $2.85 \cdot 10^{-1}$ & $6.69 \cdot 10^{-2}$ \\
\hline $\mathrm{Bi}_{22} \mathrm{~W}_{4.5} \mathrm{O}_{47.25}$ & 1.00 & $5.92 \cdot 10^{-3}$ & $7.66 \cdot 10^{-5}$ \\
\hline $\mathrm{Bi}_{22} \mathrm{~W}_{4.4} \mathrm{~V}_{0.1} \mathrm{O}_{47.25-\delta}$ & 1.02 & $7.84 \cdot 10^{-3}$ & $1.30 \cdot 10^{-4}$ \\
\hline $\mathrm{Bi}_{22} \mathrm{~W}_{5} \mathrm{O}_{48}$ & 0.92 & $1.01 \cdot 10^{-1}$ & $1.91 \cdot 10^{-2}$ \\
\hline $\mathrm{Bi}_{22} \mathrm{~W}_{4.9} \mathrm{~V}_{0.1} \mathrm{O}_{48-\delta}$ & 0.95 & $1.82 \cdot 10^{-1}$ & $3.50 \cdot 10^{-2}$
\end{tabular}


TEC of the $\mathrm{Bi}_{23} \mathrm{~W}_{4} \mathrm{O}_{46.5}$ sample is equal to $13 \cdot 10^{-6}{ }^{\circ} \mathrm{C}^{-1}$. A small peak on the cooling curve was observed at $430^{\circ} \mathrm{C}$, which can be contributed to the phase transition from cubic to tetragonal phase. The introduction of vanadium ions into bismuth tungstate structure has a positive effect on the electrical conductivity (the $\mathrm{Bi}_{23} \mathrm{~W}_{4.9} \mathrm{~V}_{0.1} \mathrm{O}_{46.5-\delta}$ has the highest value $\left.\sigma_{850}=0.13 \mathrm{Ohm}^{-1} \mathrm{~cm}^{-1}\right)$.

\section{Acknowledgements}

This work was performed within the State Assignment of the Ministry of Education and Science of the Russian Federation no. 4.2288.2017/4.6. Powder X-ray diffraction studies were performed on the equipment of the Ural-M Shared Facility Center of the Institute of Metallurgy of the Ural Branch of the Russian Academy of Sciences (IMET UB RAS).

\section{References}

1. Shuk P, Wiemhöfer H-D, Guth U, Göpel W, Greenblatt M. Oxide ion conducting solid electrolytes based on $\mathrm{Bi}_{2} \mathrm{O}_{3}$. Solid State Ionics. 1996;89:179-96.

DOI: 10.1016/0167-2738(96)00348-7.

2. Azad AM, Larose S, Akbar SA. Bismuth oxide-based solid electrolytes for fuel cells. Journal of Materials Science. 1994;29:4135-51.

DOI: $10.1007 / \mathrm{BF} 00414192$.

3. Ling CD, Johnson M. Modelling, refinement and analysis of the 'Type III' $\delta-\mathrm{Bi}_{2} \mathrm{O}_{3}$ related superstructure in the $\mathrm{Bi}_{2} \mathrm{O}_{3}-\mathrm{Nb}_{2} \mathrm{O}_{5}$ system. Journal of Solid State Chemistry. 2004;177:1838-46.

DOI: 10.1016/j.jssc.2004.01.003.

4. Firman K, Tan KB, Khaw CC, Zainal Z, Tan YP, Chen SK. Doping mechanisms and electrical properties of bismuth tantalite fluorites. Journal of Materials Science. 2017;52:10106-18.

DOI: $10.1007 / \mathrm{s} 10853-017-1216-1$.

5. Mokhosoev MV, Alekseev FP, Lutsyk VI. Diagrammy sostoyaniya molibdatnykh I vol'framatnykh system [State diagrams of molybdate and tungstate systems]. Novosibirsk: Nauka, 1978. 320 p. Russian.

6. Wind J, Auckett JE, Withers RL, Piltz RO, Maljuk A, Ling CD. Type II Bi $\mathrm{i}_{1-x} \mathrm{~W}_{x} \mathrm{O}_{1.5+1.5 x^{*}}$ : a (3+3)-dimensional commensurate modulation that stabilizes the fast-ion conducting delta phase of bismuth oxide. Acta Crystallographica B. 2015;71:679-87.

DOI: $10.1107 /$ S2052520615018351.

7. Wind J, Kayser P, Zhang Z, Evans IR, Lind CD. Stability and range of the type II $\mathrm{Bi}_{1-x} \mathrm{~W}_{x} \mathrm{O}_{1.5+1.5 x}$ solid solution. Solid State Ionics. 2017;308:173-80.

DOI: $10.1016 /$ j.ssi.2017.07.015.

8. Takahashi T, Iwahara H. High oxide ion conduction in sintered oxides of system bismuth oxide - tungsten oxide. Journal of Applied Electrochemistry. 1973;3:65-72. DOI: $10.1007 / \mathrm{BF} 01119469$.

9. Shannon RD. Revised Effective Ionic Radii and Systematic Studies of Interatomie Distances in Halides and Chalcogenides. Acta Crystallographica A. 1976;32:751-67. DOI: $10.1107 /$ S0567739476001551. 